\title{
KONFERENCE AKTUÁLNÍ TRENDY V MUZEJNÍ PREZENTACI A EDUKACI II.: VLIV DIGITÁLNÍCH TECHNOLOGIÍ NA DĚTSKÉHO NÁVŠTĚVNÍKA A MEZIOBOROVÉ PŘESAHY MUZEJNÍ PEDAGOGIKY
}

LUCIE JAGOŠOVÁ

V krásných prostorách zámeckého areálu Muzea hlavního města Prahy ve Ctěnicích proběhl ve dnech 21.-22. května 2018 pod názvem Aktuální trendy $v$ muzejní prezentaci a edukaci druhý ročník konference Komise pro práci s veřejností a muzejní pedagogiku AMG. Jeho letošním podtitulem byl Vliv digitálních technologií na dětského návštěvníka a mezioborové presahy muzejní pedagogiky. Nad konferencí s mezinárodním zastoupením převzal záštitu velvyslanec Dánského království Ole Frijs-Madsen.

Konferenci spoluorganizovalo Oddělení muzeologie Ústavu archeologie a muzeologie Filozofické fakulty Masarykovy univerzity spolu se Západočeským muzeem v Plzni, Masarykovým muzeem v Hodoníně a Metodickým centrem muzejní pedagogiky.

O účast na konferenci projevilo zájem na 120 muzejníků, akademických pracovníků a dalších odborníků z prostř̌edí kulturních institucí z České republiky i ze Slovenska.

První konferenční den zahájil blok hlavních příspěvků, reflektující poznatky z oblasti neurověd a zahraničních zkušeností. Neurolog MUDr. Martin Jan Stránský, který se specializuje na vývoj lidského mozku, jeho rozhodování a myšlení, přednášel závěry odborných výzkumů, Jak se lidský mozek učí a jak na něj působí digitální technologie. Na něj navázal dánský

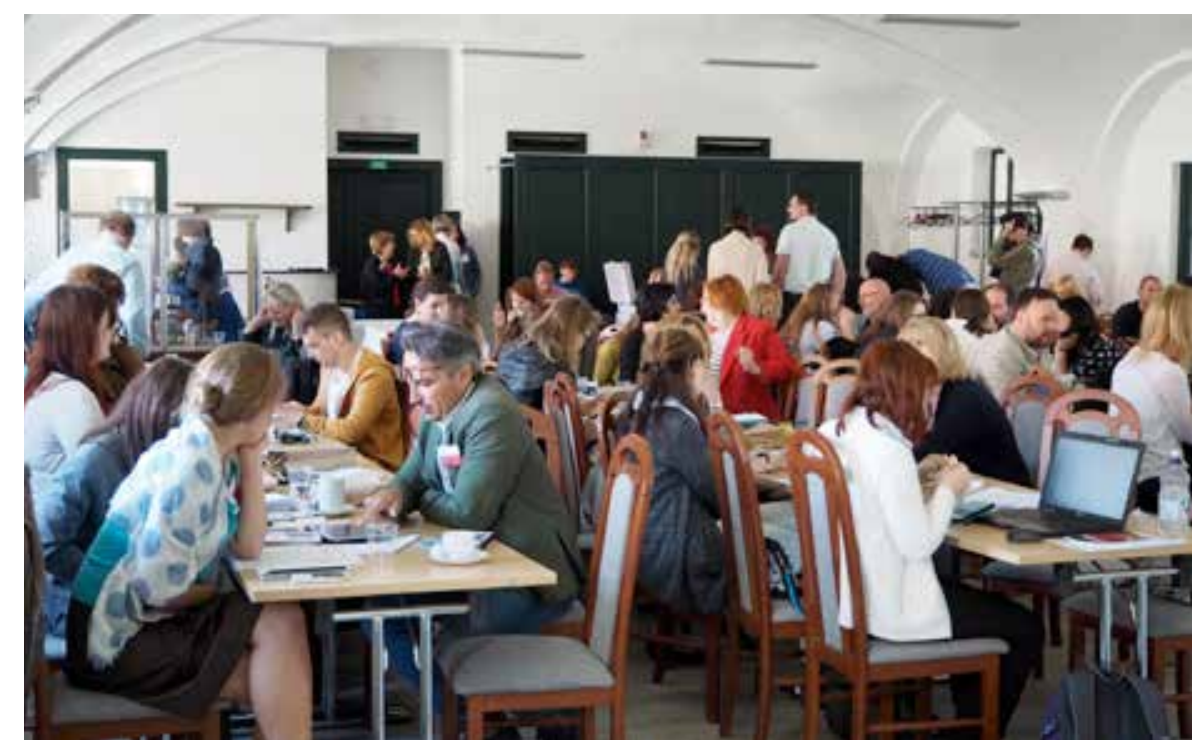

Obr. 1: Konferenční sál s účastníky (foto: Michaela Zálešáková, 2018).

historik a muzejník Martin Brandt Djupræt přednáškou Creating social spaces and personal relevance through the use of atmosphere, interaction and inclusion (Utváření sociálního prostoru a osobní zkušenosti návštěvníka prostřednictvím atmosféry, interakce a inkluze), v němž představil také stálou expozici sestavenou z ukázek městských domů z celého Dánska, zachycující objekty od středověku až po 70. léta 20. století, a v ní realizované projekty s edukačními přesahy. Blok hlavních př́ispěvků uzavřela novinářka a kulturní manažerka se zkušenostmi ze zahraničních muzeí a kulturních projektů, Judita Matyášová, příspěvkem Edukační programy ve skandinávských muzeích a skanzenech.
Další bloky byly věnovány reflexi zkušeností místních muzejních edukačních pracovníků. Zazněly příspěvky Kyberšikana@včeraadnes. cz: Digitální technologie, virtuální svět a jejich rizika jako téma sociálně preventivního projektu (Jitka Králová, Regionální muzeum Mělník), Nová média, literatura, písmo a text, ekologie a environment (Lucie Haškovcová, Markéta Slachová Goldová, Kateřina Prokopová, Galerie hl. m. Prahy), Možnosti využití tabletů při interpretaci sbírkových předmětů (Iva Vachková, Muzeum hl. m. Prahy). Podvečerní čas byl věnován prezentaci muzejněpedagogických aktivit a zážitkových výstav Zámeckého areálu Ctěnice a následný společenský večer byl prostorem pro neformální setkání účastníků konference. 


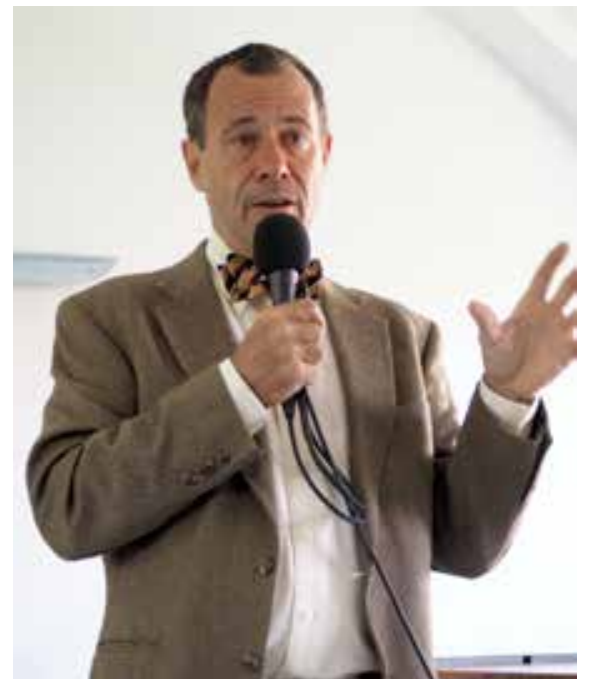

Obr. 2: Přednášející Martin Jan Stránský (foto: Michaela Zálešáková, 2018).

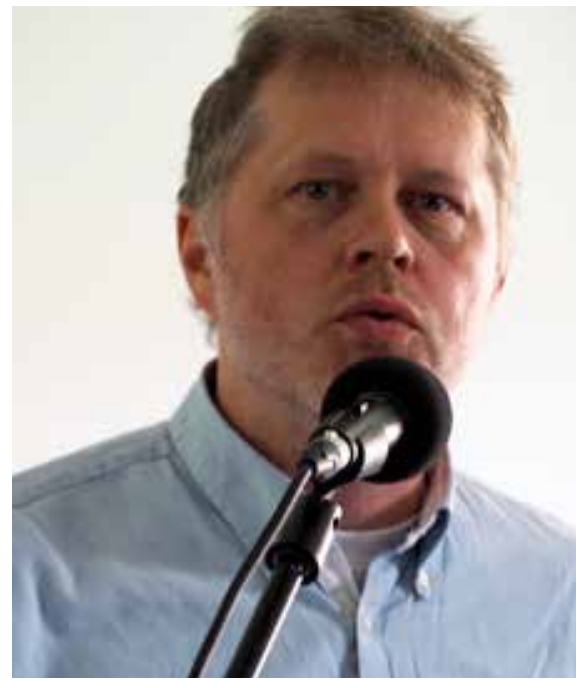

Obr. 3: Přednášející Martin Brandt Djupræt (foto: Michaela Zálešáková, 2018).

Druhý konferenční den zahájilo Otevřené plenární zasedání členské základny Komise pro práci s veřejností a muzejní pedagogiku AMG s možnou širokou účastí hostů. Poté zazněly opět konferenční příspěvky, tentokrát reflektující spolupráci a mezioborové přesahy muzejní pedagogiky. Pohledu optikou zkušeností ze školního vzdělávání se

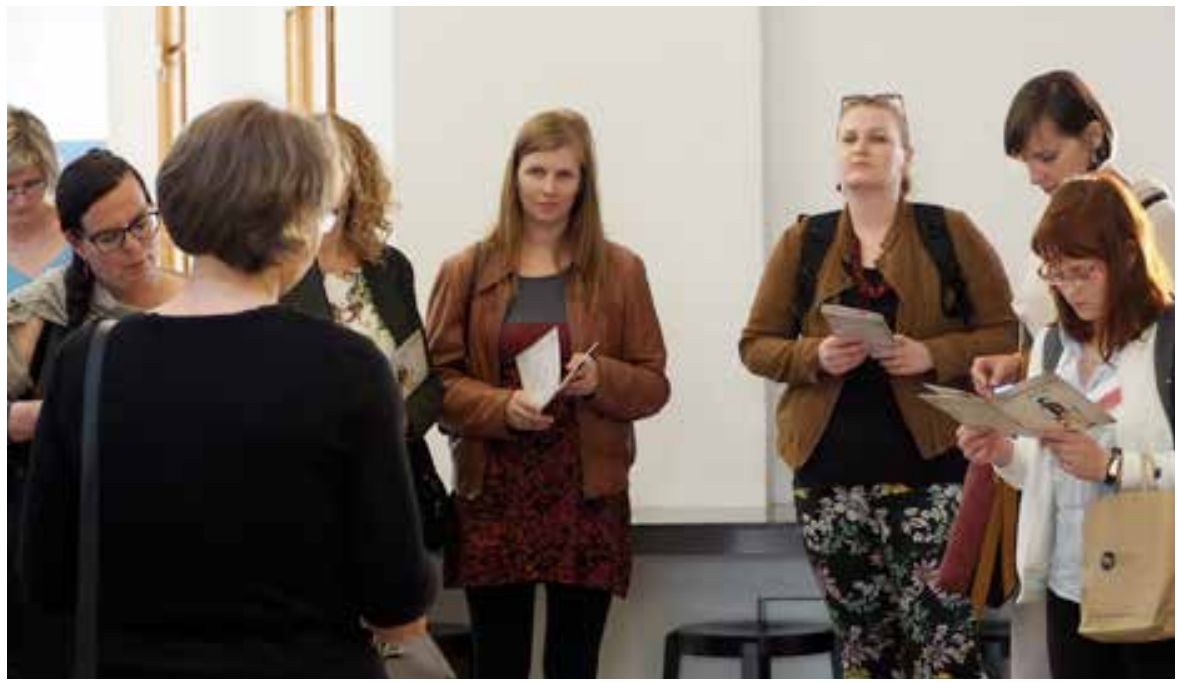

Obr. 4: Program ve výstavních prostorách muzea (foto: Michaela Zálešáková, 2018).

věnoval příspěvek Vhled do aktuálních strategií efektivního využivání digitálních technologií ve školní výuce (Kateřina Tomešková, Národní pedagogické muzeum a knihovna J. A. Komenského, Praha), praktické využití digitálních technologií ve svých expozicích a výstavách prezentovaly příspěvky Digitální svět není soupeř aneb Použití tabletů a chytrých telefonů $v$ expozicích, na výstavách a $v$ projektech muzejní pedagogiky $v$ NTM (Ivana Lorencová) a Využití nových technologií $v$ propojování expozic $v$ Muzeu Blanenska (Pavlína Komínková, Daniela Pietraszová). Využívání metod běžných $v$ muzejní didaktice $\mathrm{v}$ prostředí jiných oborů zastupovaly svými tématy př́spěvky Kupci už jsou tu aneb Inscenační meto$d y$ a role playing $v$ archeologické edukaci (Veronika Puhačová, Ústav archeologické památkové péče středních Čech), Konkurují si knihovní a muzejní pedagogika? (Klára Smolíková). Během konference také zazněly tematické firemní prezentace iPublishing, 3Djohny a Projektmedia s.r.o.
Konferenci uzavřely exkurzní výjezdy do objektů spravovaných Muzeem hl. m. Prahy s výkladem a informacemi o lektorských programech. Účastníci konference si mohli vybrat návštěvu Novomlýnské vodárenské věže, Domu U Zlatého prstenu anebo Langweilova modelu Prahy a programu s tablety Revoluční Praha 1848.

Za výbor Komise pro práci s veřejností a muzejní pedagogiku AMG bych ráda poděkovala všem spoluorganizátorům, přednášejícím i účastníkům za podíl na úspěšném průběhu akce, která jistě přinesla inspiraci a řadu podnětů z mezinárodního i lokálního prostředí. Těšíme se na setkání opět na dalším ročníku konference Aktuální trendy $v$ muzejní prezentaci a edukaci $\mathrm{v}$ prríštím roce.

\section{LUCIE JAGOŠOVÁ}

Ústav archeologie a muzeologie, Filozofická fakulta, Masarykova univerzita, Brno, Česká republika 